\title{
Chinese Dynasties of the Late Empire
}

\author{
SONG \\ $960-1279$ \\ YUAN (MONGOL) 1279-1368 \\ MING \\ 1368-1644 \\ QING (MANCHU) 1644-1911
}





\section{CHINA'S MO'TOR}

